\title{
Pengaruh aplikasi teknologi, accounting reporting Terhadap pencegahan fraud serta implikasinya Terhadap reaksi investor
}

Oleh :

\author{
Yulita Zanaria ${ }^{1}$ \\ Universitas Muhammadiyah Metro \\ YulitaZanaria13@gmail.com
}

\begin{abstract}
The purpose of this research is to examine the impact of information technology, accounting reporting toward fraud detection in companies that listed on Indonesia Stock Exchange. Baside that, this research to examine implication of fraund detection to investor reaction.

The population of the study is the LQ 45 companis registered in the Indonesia Stock Exchange in the periode of 2010-2014. Shampling technique employed in this study is the purposive sampling whit the total sample of 90 companies The data analysis uses Amos software, The result of the study show yhat the dividend policy, information technology, accounting reporting have significant influence towards frund detection. The other result showed that fraund detection have significant influence towards investor reaction.
\end{abstract}

Keywords :information technology, accounting reporting, fraund detection, investor reaction.

\section{PENDAHULUAN \\ Latar Belakang}

Menarik minat investor untuk berinvestasi merupakan tujuan dari perusahaan dalam mengembangkan usahanya. Untuk itu dibutuhkan tehnik dan strategi khusus bagi pihak perusahaan untuk menarik minat para investor. Umumnya, dalam proses pengambilan keputusan investasi, para investor cendrung menanamkan modalnya pada perusahaan yang memiliki kepedulian terhadap masalah-masalah social dan lingkungan hidup (Pinnarwan dalam Zahro dan Sukmawati, 2003). Perusahaan-perusahaan yang lebih banyak mengungkapkan informasi social yang dibutuhkan oleh investor tentunya akan mendapatkan kepercayaan dari masyarakat.

Dengan meningkatnya kepercayaan masyarakat terhadap perusahaan yang melakukan pengungkapan diharapkan menjadi pendorong naiknya volume perdagangan saham, dan return saham pada perusahaan yang dianggap sebagai pendorong adanya reaksi investor dalam pengambilan keputusan investasi. Untuk menarik minat investor dalam menanamkan modalnya, pihak perusahaan harus bekerja keras agar laporan yang mereka sajukan bebas dari salah saji dan kecurangan fraund.

Menurut SAS no.99, terhadap empat jenis tekanan yang mungkin mengakibatkan kecurangan pada laporan keuangan. Jenis tekanan tersebut adalah fianancial stability, external pressure, personal financial need, dan financial targets. Financial statement frund sering kali diawali dengan salah saji atau menajemen laba dari laporan keuangan kuartal yang dianggap tidak material tetapi akhirnya tumbuh menjadi frund secara besar-besaran dan menghasilkan laporan keuangan tahunan yang menyesatkan secara material (Rezaee, 2002 ). Kecurangan pada laporan keuangan akan mengakibatkan kesalahan persepsi oleh auditor dan pengguna laporan keuangan lainnya karena tidak menampilkan kondisi perusahaan yang sesungguhnya, Hal tersebut akan membawa dampak kerugian bagi para pelaku bisnis.

Salah satu yang bisa dilakukan pihak manajemen perusahaan untuk mencegah frund adalah dengan melakukan pengendalian di bidang teknologi.

\footnotetext{
${ }^{1}$ Dosen FAKULTAS Ekonomi Universitas Muhammadiyah Metro
} 
Teknologi informasi dicanangkan untuk membantu perusahaan dalam melaksanakan kegiatan operasional sehari-hari.Impelementasi teknologi informasi dalam perusahaan membuat kinerja semakin meningkat.Dengan teknologi informasi yang sistematis dan terintegrasi akan semakin mempersempit celah terjadinya fraud dalam perusahaan. Selain teknologi informasi, factor lain yang tak kalah penting dalam pencegahan frund adalah accounting reporting.

Accounting reporting merupakan komponen penting untuk menciptakan akuntabilitas organisasi.Adanya tuntutan yang semakin besar terhadappelaksanaanakuntabilitas public menimbulkan implikasi bagi manajemen untuk memberikan informasi kepada public, salah satunya adalah informasi akuntansi yang nerupa laporan keuangan. Tantangan yang dihadapi accounting reporting adalah rnampukan akuntansi menyediakan informasi yang dapat digunakan untuk memonitor akuntabilitas manajemen, akuntabilitas politik, dan akuntabilitas kebijakkan. Salah satu bentuk pencegahan fraud adalah dengan menyajikan accounting reporting yang sesungguhnya dengan mempertimbangkan hal penerapan kebijakan sistem dan prosedur yang membantu menyakinkan bahwa tindakan yang diperlukan sudah dilakukan dewan komisaris, serta manajernen dan personil lain perusahaan untuk dapat memberikan kenyakinan memadai. Penelitian ini mencoba menelan pengaruh aplikasi teknologi informasi, accounting reporting terhadap pencegahan fraud serta implikasinya terhadap reaksi investor dalam menilai kinerja perusahaan.

\section{KAJIAN TEORETIK \\ Teknologi Informasi}

Teknologi informasi sudah menjadi pilihan utama dalam menciptakan system informasi suatu organisasi yang tangguh dan mampu melahirkan keunggulan kompetitif ditengah persaingan yang semakin ketat dewasa ini.Investasi dibidang teknologi informasi dalam suatu organisasi umumnya dimaksudkan untuk memberikan kontribusi terhadap kinerja individual anggota organisasi dan institusi. Selain itu, penggunaan teknologiinformasi juga akan mempermudah dan mempercepat kegiatan organisasi. Sehingga, para pegawai dapat melaksanakan tugasnya secara ekonomis, efisien dan efektif.

Menurut O'Brien (2006) teknologi adalah suatu jaringan computer yang terdiri atas berbagai komponen pemrosesan informasi yang menggunakan berbagai jenis hardware, software, manajemen data, dan teknologi jaringan informasi. Menurut Aji (2005) informasi adalah data yang terolah dan sifatnya menjadi data lain yang bermanfaat dan bisa disebut informasi. Pemanfatan teknologi informasi juga memberikan banyak bagi lembaga non pemerintah.Mahmood dan Mann (1993) menyatakan bahwa investasi yang mantap dalam, teknologi informasi harus dipertimbangkan untuk meningkatkan performance ekonomi dan strategi organisasi. Dengan investasi dalam TI yang tepat maka perusahaan akan, memiliki suatu keunggulan kompetitif sehingga mampu barsaing dalam perusahaan dan keberhasilan dalam persaingan akan dapat meningkatkan kinerja perusahaan dalam bentuk output perusahaan, dan nilai perusahaan yang ditunjukkan dengan nilai saham perusahaan.

Pemanfaatan teknologi informasi menurut Thomson et al. (1991) dalam Tjhai(2003) merupakan manfaat yang diharapkan oleh pengguna system informasi dalam melaksanakan tugasnya atau perilaku dalam menggunakan teknologi pada saat melakukan pekerjaan. Pengukurannya berdasarkan intensitas pemanfaatan, frekuensi pemanfaatan, dan jumlah aplikasi atau perangkat lunak yang digunakan.Pemanfaatan teknologi informasi yang tepat dan didukung oleh keahlian personil yang mengoprasikannya dapat meningkatkan kinerja perusahaan maupun kinerja individu yang bersangkutan.Perana TI dalam berbagai aspek kegiatan bisnis dapat dipahami karena sebagai sebuah teknologi yang menitik beratkan pada pengaturan system informasi dengan penggunaan computer, TI dapat memenuhi kebutuhan informasi dunia bisnis dengan sangat cepat, tepat waktu, relevan, dan akurat (Wilkinson danCerullo, 1997).

\section{Accounting Reporting}


Laporan keuangan merupakan bentuk pertanggung jawaban atas kepengurusan sumber daya ekonomi yang memiliki oleh suatu entitas (Deddi Nordiwan, 2007). Seperti yang diungkap pula oleh Kieso, Weygant (2005) bahwa, report that measure the success of enterprise operations for given period of time. Sedangkan menurut Peraturan Pemerintah Nomor 24 Tahun 2005, Laporan Keuangan merupakan laporan terstruktur mengenai posisi keuangan dan transaksi-transaksi yang dilakukan oleh entitas pelaporan.

Tujuan penyajian laporan keuangan menurut Jones (2000) yaitu "To provide (1) financial information usefull for making economic and (2) information esefull for evaluating managerial and organizational performance". Sedangkan Wolk (2001) menyatakan bahwa: "An objective of financial statements forgovernmental and not-for-profit organization is to provide information iseful for evaluating the effectiveness of the management of resources in achieving the organization's goals. Dalam PSAK no 45 " Pelapor Keuangan Organisasi Nirbala" mengemukakan tujua utama laporan keuangan adalah menyediakan informasi yang relevan untuk memenuhi kepentingan para penyumbang, anggota organisasi, kreditur dan pihak lain yang menyediakan sumber daya bagi kegiatan organisasi nirbala.

\section{Fraud}

Dalam kamus Bahasa Ingris-Indonesia (Echols, 1989), fraud berarti (1) penipuan, (2) seorang penipu atau gadungan, (3) kecurangan, (4) penggelapan. Jones dan Bates (Jones, 1990) dalam Public Sector Auditing menyatakan fraud dalam Thef Act 1968adalah penggelapan yang meliputi berbagai kecurangan, antara lain penipuan yang disengaja (international deceit), pemalsuan rekening (falsification of account), praktek jahat (corrupt practices), penggelapan atau pencurian (embezzlement), korupsi (corruption) dan sebagainya. Fraud terjadi dimana seseorang memperoleh kekayaan atau keuntungan keuangan melalui kecurangan atau penipuan.Kecurangan sepacam ini menunjukkan adanya keinginan yang disengaja, tidak termasuk ketidaktahuan.

Sedangkan menurut Jones (Jones 1993), fraud merupakan kesalahan desengaja yang dikelompokkan de dalam dua tipe, yaitu : (1) fraudulent financial reporting, yang meliputi: manipulasi, pemalsuan, atau pengubahan catatan akuntansi atau document pendukung dan laporan keuangan yang disusun, tidak menyajikan dalam atau sengaja menghilangkan kejadian, transaksi, dan informasi penting dan laporan keuangan, dan sengaja menerapkan prinsip akuntansi yang salah, (2) missapropration of asset, yang meliputi penggelapan penerimaan kas, pencurian aktiva, dan hal-hal yang menyebabkan suatu entitas membayar untuk barang atau jasa yang tidak diterimanya.

\section{Reaksi Investor}

Investor adalan individu, kelompok, atau badan hukum yang melakukan penanaman modal pada suatu unit usaha tertentu. Reaksi investor ditunjukkan dengan adanya perubahan harga saham perusahaan tertentu yang cukup mencolok dari satu sekuritas yang bersangkutan pada saat pengumuman laba. Yang dimaksud dengan mencolok adalah terdapat perbedaan yang cukup besar antara return yang terjadi (actual return) denganreturn harapan expected return. Reaksi investor (pasar) ditunjukkan dengan adanya perubahan harga saham (return saham) perusahaan tertentu yang mencolok pada saat pengumuman laba yaitu terdapat perbedaan yang cukup besar antara return yang terjadi dengan return harapan (Suwardjono, 2005).

\section{Pengembangan hipotesis \\ Teknologi informasi berpengaruh terhadap pencegahan fraud}

Teknologi informasi telah membawa perubahan yang sangat mendasar bagi organisasi baik swasta maupun organisasi public.Oleh karena itu, teknologi informasi menjadi suatu hal yang sangat penting dalam menentukan daya saing dan kemampuan perusahan untuk meningkatkan kinerja bisnis dimasa mendatang.Sumber daya teknologi informasi menjadi sebuah pertimbangan baik itu bagi para manager dan konsultan, dalam menentukan keberhasilan perusahaan dimasa mendatang (Devaraj dan Kholi, 2003).Implemintasi teknologi informasi 
dapat memenuhi kebutuhan informasi dunia bisnis dengan sangat cepat, tepat waktu, relevan, dan akurat (Wilkinson dan Cerullo, 1997). Adanya implemintasi teknologi informasi yang membantu kegiatan perusahaan dalam menghasilkan informasi yang akurat tentunya sangat membantu mencegah terjadinya kecurangan dalam organisasi perusahaan,. Berdasarkan hal tersebut maka dikemukakan hipotesis sebagai berikut :

H1 : Teknologi Informasi berpengaruh terhadap pencegah fraud

\section{Accounting reporting berpengaruh terhadap pencegahan fraud}

Accounting reportingmerupakan komponen penting untuk menciptakan akuntabilitas organisasi. Salah satu bentuk pencegahan fraud adalah dengan menyajikan accounting reporting yang sesungguhnya dengan mempertimbangkan hal penerapan kebijakkan, system dan prosedur yang membantu menyakinkan bahwa tindakkan yang dilakukan sudah dilakukan dewan komisaris, serta manajernen dan personil lain perusahaan untuk dapat memberikan kenyakinan memadai. Penelitian yang dilakukan oleh Santoso (2008) membuktikan bahwa penerapan accounting report di sector public terbukti mencegah terjadinya fraud. Berdasarakan paparan di atas maka dikemukakan hipotesisi sebagai berikut :

$\mathrm{H} 2$ : Accounting reporting berpengaruh terdapat pencegahan fraud

\section{Implikasi Pencegahan Fraud Terhadap Reaksi Investor}

Adanya usaha maksimal dari pihak perusahaan dalam mencegah terjadinya fraud tentu membawa efek positif di mata investor.Investor dapat melihat kinerja perusahaan berdasarkan informasi dari laporan keuangan yang disajikan pihak perusahaan.Dari laporan keuangan ini tersirat usaha yang dilakukan perusahaan agar kegiatan operasi sehari-hari mereka bebas dari unsure fraud.Kebijakkan yang ditetapkan perusahaan, tehnik pencatatan yang dilakukan dapat diketahui dari informasi yang disajikan pihak perusahaan melalui laporan keuangnnya.

Riset yang dilakukan oleh Wibowo dkk (2009) menunjukkan hasil bahwa adanya penerapan fraud warning system dengan metode whistle blowing systemmemberikan manfaat bagi organisasi sebagai penampung informasi pihak internal perusahaan untuk mengungkapkan, melaporkan kecurangan yang terjadi. Perusahaan-perusahaan yang telah melakukan pencegahan dini terhadap fraud memberikan reaksi positif di mata investor. Investor menilai bahwa perusahaan yang telah menerapkan fraud warning system dalam organisasi mereka, menunjukkan bahwa perusahaan telah berusaha maksimal dalam mengelola organisasi untuk meningkatkan kinerja organisasi (Reinsten, Husband, Bayau 1999) dalam Wibowo (2009). Berdasarkan paparan di atas, maka diajukan hipotesis sebagai berikut :

H3 : Pencegahan fraud berpengaruh terhadap reaksi investor

\section{Model Penelitian}

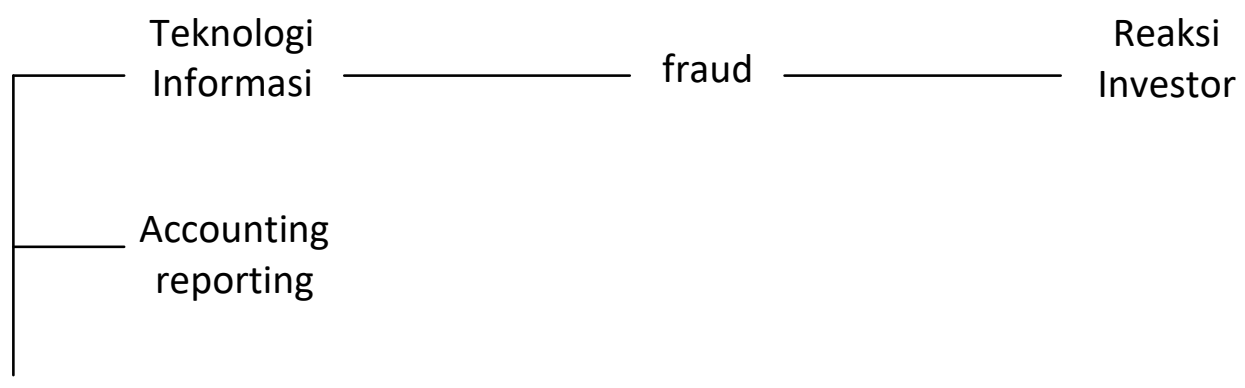

\section{METODE PENELITIAN \\ Populasi dan Sample}

Populasi yang akan menjadi objek penelitian adalah perusahaan- perusahaan LQ 45 yang terdaftar di Bursa Efek Jakarta periode 2010-2014. Pemilihan sample perusahaan LQ 45 pada penelitian ini dikarenakan perusahaan LQ 45 di Indonesia rentan terhadap perubahan yang terjadi di bidang lainnya seperti bidang social, politik, keamanan, baik yang terjadi di dalam 
negeri. Bursa Efek Jakarta merupakan pasar saham terbesar dan paling refresintatif di Indonesia. Berdasarkan populasi tersebut dapat ditentukan sample yang menjadi objek penelitian ini.

\section{Tehnik Pengambilan Sample}

Dalam penentuan sample tersebut, tehnik sampling yang dipergunakan adalah purposive sampling yaitu metode pengambilan sampling berdasarkan criteria-kriteria tertentu (Masri Singaribun dan Sofian Effendi, 1995).

\section{Uji Normalitas Data}

Uji statistic yang digunakan untuk menguji normalitas adalah uji statistic non parametricOne Kolmogorov Smirnov.Jika angka probabilitas $<\square=0,05$ maka variable tidak terdistribusi secara normal. Sebaliknya, bila angka Probabilitas $\langle\square=0,05$ maka variable terdistribusi secara normal (Imam Ghozali, 2005)

\section{Uji Hipotesis}

Uji hipotesis menggunakan teknik Multivariate Structur Equation Model (SEM).Pemodelan SEM terdiri dari model pengukuran (measuremenr model) dan model struktrual (structurual model). Model structural ditujukan untuk menguji hubungan antara konstruk eksogen dan endogen. Sedangkan model pengukuran ditujukan untuk menguji hubungan antara indicator dengan konstruk / variable laten Ballen (1989) dalam Imam Al Ghozali (2005). Adapun software yang digunakan dalam penelitian ini adalah Amos ver 20.

\section{HASIL PENELITIAN \\ Deskripsi Variable}

Gambaran mengenai variable-variable penelitian yaitu teknologi informasi, accounting report, farud dan reaksi investor disajikan dalam table statistic deskriptif yang menunjukkan angka kisaran teoritis dan sesungguhnya, rata-rata standar deviasi dapat dilihat dalam table 4.1 .apabila nilai rata-rata jawaban tidak konstruk pada kisaran sesungguhnya dibawah kisara ratarata kisaran teoritis maka dapat diartikan bahwa pengaruh variable yang diteliti terhadap responden cendrung rendah. Begitu pula sebaliknya jika nilai rata-rata kisaran sesungguhnya di atas rata-rata kisaran teoritis, maka pengaruh variable yang diteliti terhadap responden cebderung tinggi.

Tabel I

Statistik Deskripsi Variable penelitian

Descriptive statistics

\begin{tabular}{|l|r|r|r|r|r|r|}
\hline & \multicolumn{1}{|c|}{$\mathrm{N}$} & \multicolumn{1}{c|}{ Minimum } & \multicolumn{1}{c|}{ maximum } & \multicolumn{2}{|c|}{ mean } & \multicolumn{1}{c|}{ Std. Deviation } \\
\cline { 2 - 7 } & Statistic & Statistic & Statistic & Statistic & Std. Error & \multicolumn{1}{c|}{ Statistic } \\
\hline TI & 90 & 12.331 & 22.841 & 17.234 & .897 & 12.349 \\
AC & 90 & 11.445 & 23.063 & 18.890 & .145 & 13.543 \\
FR & 90 & 13.442 & 23.982 & 16.812 & .467 & 13.990 \\
RI & 90 & 11.255 & 20.891 & 16.213 & .234 & 12.232 \\
Valid N & 90 & & & & & \\
(listwise) & & & & & & \\
\hline
\end{tabular}

Berdasarkan tabel diatas maka dapat diketahui bahwa Variable teknologi informasi memiliki nilai minimum 12,331, nilai maksimum 22,841, rata-rata 17,234 dan standar deviasi sebesar 12,349. Nilai standar deviasi yang lebih kecil dari nilai rata-rata menandakan perbedaan penggunaan teknologi informasi antar perusahaan adalah kecil. Nilai mean yang positif menunjukkan bahwa rata-rata perusahaan yang diteliti menggunakan teknologi informasi dalam kegiatan operasionalnya.

Variable accounting reporting memiliki nilai minimum 11,455 nilai maksimum 23,063 rata-rata 18,890 , dan standar deviasi sebesar 13,543 . Nilai standar deviasi yang lebih kecil dari 
nilai rata-rata menandakan perbedaan accounting reporting antar perusahaa adalah kecil. Nilai mean yang positif menunjukkan bahwa rata-rata perusahaan yang diteliti melakukan aktivitas accounting report. Variable Fraud memiliki nilai minimum 13,442 nilai maksimum 23,982 ratarata 16,812 dan standar deviasi sebesar 13,990.Nilai standar deviasi yang lebih kecil dari nilai rat-rata menandakan perbedaan lamanya pencegahan Fraud anatar perusahaan adalah kecil. Variable raksi investor memiliki nilai minimum 11,256 nilai maksimum 20,891 rata-rata 16, 213 dan standar deviasi sebesar 12, 232. Nilai standar deviasi yang lebih kecil dari nilai rata-rata menandakan perbedaan reaksi investor terlalu jauh untuk masing-masing perusahaan.

\section{Uji Normalitas}

Berikut tampilan uji normalitas data dari hasil olah menggunakan program bantuan software SPSS

Tabel .2.

Hasil Uji Normalitas

One-Sample Kolmogorov-Smirnov Test

\begin{tabular}{|ll|r|}
\hline & & Unstandardized Residual \\
\hline $\mathrm{N}$ & Mean & 90 \\
Normal parameters & & .0000000 \\
Most Extreme Differences & Std. Deviation & 4.14523562 \\
& & .234 \\
& Absolute & .023 \\
Koimogorov-Smirnov Z & & -.234 \\
Asymo. Sig. (2-teiled) & & .552 \\
Ty & .578 \\
\hline
\end{tabular}

a. Test distribution is normal.

b. Calculate from data

Berdasarkan hasil outpot diatas, variable dinyatakan menyebar dengan normal jika hasil uji kolmogorov smirnov standardized residual menunjukkan jika nilai assympatic significant (2-tailed) > alpha $(0,05)$. Pada table, dapat diketahui bahwa nilai kolmogorov smirnov test sebesar 0,552 sedangkan nilai asymp. Sig. (2-tailed)0,578 lebih besar dari nilai a yaitu 0,05, sehingga dapat disimpulkan bahwa data yang digunakan berdistribusi normal.

\section{Uji Hipotesis}

Setelah dijuji normalitas dan outlier menggunakan Amos, data bisa diajukan untuk pengajuan hipotesis. Ringkasan perbandingan model yang dibaangun dengan cut of goodness of fit indices yang ditetapkan, Nampak pada table berikut :

Tabel 3

Goodness-of-fit Indices

Full Structural Equation model

\begin{tabular}{|c|c|c|c|}
\hline Goodness of fit index & Cut-off value & Hasil Model & Keterangan \\
\hline Chi-Square & Diharapkan kecil & 171,641 & \\
\hline Probability & $\geq 0,05$ & 0,450 & Marjinal \\
\hline RMSEA & $\geq 0,08$ & 0,088 & Marjinal \\
GFI & $\geq 0,90$ & 0,871 & Marjinal \\
\hline AGFI & $\geq 0,90$ & 0,899 & Marjinal \\
\hline CMIN/DF & $\leq 2,00$ & 1,973 & fit \\
\hline TLI & $\geq 0,95$ & 0,951 & fit \\
\hline CFI & $\geq 0,95$ & 0,964 & fit \\
\hline
\end{tabular}

Sumber: data primer diolah 
Kriteria-kriteriaaa Index menunjukan tingkat penerimaan yang baik yang semuanya meeenunjukkan nilai fit yang sesuai. Untuk menguji hipotesis yang diajukan, dapat dilihat besarnya Critical Ration dan probabilitas pada output regression weight berikut pada tabel 4

Tabel 4

Output Regression Weights

\begin{tabular}{|c|l|c|c|c|c|c|c|}
\hline & & & Estimate & S.E & C.R & P & LABEL \\
\hline FR & $<---$ & TI & 1,551 &, 152 & 10,199 & $* * *$ & Par_10 \\
\hline FR & $<---$ & AR & 1,722 &, 163 & 10,559 & $* * *$ & Par_18 \\
\hline RI & $<---$ & FR &, 236 &, 062 & 3,821 & $* * *$ & Par_19 \\
\hline X23 & $<---$ & TI & 1,000 & & & & \\
\hline X22 & $<---$ & TI & 1,023 &, 038 & 26,570 & $* * *$ & Par_3 \\
\hline X4 & $<---$ & AR & 1,000 & & & & \\
\hline X3 & $<---$ & AR & 1,279 &, 084 & 15,296 & $* * *$ & Par_4 \\
\hline X8 & $<---$ & FR & 1.000 & & & & \\
\hline X7 & $<---$ & FR & 1,289 &, 090 & 14,370 & $* * *$ & Par_5 \\
\hline X16 & $<---$ & RI & 1,000 & & & & \\
\hline
\end{tabular}

Sumber : data peimer diolah

Keterangan :

$\begin{array}{ll}\text { TI } & : \text { Teknologi Informasi } \\ \text { AR } & : \text { Accounting Reporting } \\ \text { FR } & : \text { Fraud } \\ \text { RI } & : \text { Reaksi Investor }\end{array}$

\section{Pembahasan}

\section{Teknologi informasi berpengaruh terhadap pencegahan fraud}

Hipotesis 2 yang menyatakan bahwa teknologi informasi berpengaruh terhadap pencegahan fraud. Hasil uji terhadap parameter estimasi (standardized regression weight) antara teknologi informasi (TI) terhadap pencegahan Farud (FR) menunjukkan adanya pengaruh positif 1,551 dengan nilai critical ration (CR) sebesar 10,991 dan nilai p-value menunjukkan tanda *** yang berarti signifikan. Nilai CR tersebut berada jauh diatas nilai kritis $\pm 1,96$ dengan tingkat signifikan $* * *$ (artinya signifikan) yaitu $p$ berada dibawah nilai signifikan 0.05 . dengan demikian hipotesis kedua dapat diterima.

Hasil ini menunjukkan bahwa adanya implemintasi teknologi informasi yang membantu kegiatan perusahaan dalam menghasilkan informasi yang akurat berdampak sangat membantu mencegah terjadinya kecurangan (fraud) dalam organisasi perusahaan. Hasil penelitian ini sesuai dengan pernyataan yang dikemukakan oleh Wilkinson dan Cerullo (1997) yang mengatakan bahwa implementasi teknologi informasi dapat memenuhi kebutuhan informasi dunia bisnis dengan sangat cepat, tepat waktu, relevan, dan akurat sehingga mampu meminimalisir kesalahan baik yang disengaja maupun tidak.

\section{Accounting Reporting berpengaruh terhadap pencegahan fraud}

Hipotesis pertama (H3) menyatakan bahwa accounting reporting berpengaruh terhadap. Pencegahan fraud Hasil uji terhadap parameter estimasi (standardized regression weight)antara accounting reporting (AR) terhadap pencegahan fraud (FR) menunjukkan ada pengaruh positif 1,772 dengan nilai critical ration (CR) sebesar 10,559dan nilai p-value menunjukkan tanda $* * *$ yang berarti signifikan. Nilai CR tersebut berada jauh diatas nilai kritis +1.96 dengan tingkat signifikasi $* * *$ (artinya signifikan ) yaitu p berada di bawah nilai signifikan 0,05 . Dengan demikian hipotesis ketiga dengan menyatakan accounting reporting berpengaruh terhadap pencegahan fraud diterima. 
Accounting reporting merupakan komponen penting untuk menciptakan akuntibilitas organisasi. Salah satu bentuk pencegahan fraud adalah dengan menyajikan accounting reporting yang sesungguhnya dengan mempertimbangkan hal penerapan kebijakkan, system dan prosedur yang membantu menyakinkan bahwa tindakkan yang diperlukan sudah dilakukan dewan komisaris, serta manajernen dan personil lain perusahaan untuk dapat memberikan kenyakinan memadai. Hasil penelitian ini mendukung penelitian yang dilakukan oleh santoso (2008) yang membuktikan bahwa penerapan accounting report di sector public terbukti mencegah terjadinya fraud.

\section{Pencegaha fraud berpengaruh terhadap reaksi investor}

Hipotesis keempat (H4) menyatakan bahwa pencegahan fraud berpengaruh terhadap reaksi investor. Hasil uji terhadap parameter estimasi (standardized regression weight) antara pencegah fraud (FR) terhadap reksi investor (RI) menunjukkan ada pengaruh positif 0,236 dengan nilai Critical Ration (CR) sebesar 3,812 dan nilai p-value menunjukkan tanda $* * *$ yang berarti signifikan. Nilai CR tersebut berada jauh di atas nilai kritis \pm 1.96 dengan tingkat signifikan $* * *$ (artinya signifikan) yaitu $p$ berada dibawah nilai signifikan 0.05. dengan demikian hipotesis ketiga yang menyatakan pencegahan fraud berpengaruh terhadap reaksi investor diterima.

Hasil ini mendukung penelitian sebelumnya (Wibowo,2009) dan Reinsren et al (1991) yang membuktikan bahwa adanya penerapan fraud warning system dengan metode whistle blowing system memberikan reaksi positif di mata investor. Investor menilai bahwa perusahaan yang telah menerapkan fraud warning system dalam organisasi mereka dengan tujuan mencegah terjadinya kecurangan baik pihak internal maupun eksternal perusahaan, menunjukkan bahwa perusahaan telah berusaha maksimal dalam mengelola organisasi untuk meningkatkan kinerja organisasi.

\section{KESIMPULAN DAN SARAN \\ Kesimpulan}

Kesimpulan dari penelitian ini adalah sebagai berikut :

1. Teknologi informasi terbukti berpengaruh terhadap pencegahan fraud. Adanya implemintasi teknologi informasi yang membantu kegiatan perusahaan dalam menghasilkan informasi yang akurat berdampak sangat membantu mencegah terjadinya kecurangan (fraud) dalam organisasi perusahaan. Hasil penelitian ini sesuai dengan pernyataan yang dikemukakan oleh Wilkinson dan Cerullo (1997) yang mengatakan bahwa implementasi teknologi informasi dapat memenuhi kebutuhan informasi dunia bisnis dengan sangat cepat,tepat waktu, relevan dan akurat sehingga mampu meminimalisir kesalahan baik yang disengaja ataupun tidak.

2. Accounting reporting terbukti berpengaruh terhadap reaksi investor. Hasil penelitian ini mendukung penelitian yang dilakukan oleh santoso (2008) yang membuktikan bahwa penerapan accounting report di sector public terbukti mencegah terjadinya farud.

3. Pencegahan fraud terbukti berpengaruh terhadap reaksi investor. Hasil penelitian ini mendukug penelitian sebelumnya (wibowo,2009) dan reinsren et al (1991) yang membuktikan bahwa adanya penerapan fraud warning system dengan metode whistle blowing system memberikan reaksi positif dimata investor. Investor menilai bahwa perusahaan yang telah menerapkan fraud warning system dalam organisasi mereka dengan tujuan mencegah terjadinya kecurangan baik dari pihak internal maupun eksternal perusahaan, menunjukkan bahwa perusahaan telah berusaha maksimal dalam mengelola organisasi untuk meningkatkan kinerja organisasi.

\section{Saran}

Adapun saran-saran yang dapat penulis berikan sehubungan dengan keterbatasan dalam penelitian ini adalah sebagai berikut : 
1. Bagi perusahaan untuk meningkatkan kepercayaan pemegang saham terhadap perusahaan, maka perusahaan harus mampu menunjukkan kinerja perusahaan yang bagus dan menyampaikan informasi yang cukup kepada investor mengenai perkembangan perusahaan.

2. Bagi para investor dan calon investor, sebelum melakukan investasi sebaiknya sebaiknya mencari tahu mengenai profile perusahaan dan informasi-informasi yang diungkap oleh perusahaan emiten, apakah memenuhi kebutuhan informasi dalam analisis investasi.

3. Bagi penelitian selanjutnya diharapkan dapat menggunkan jenis perusahaan yang berbeda dan memakai ruang lingkup sampel yang luas. Selain itu juga diharapkan dapat menambah variable-variable lain yang dapat memepengaruhi pencegaah fraud seperti system pengendalian internal perusahaan serta reaksi investor seperti earning, tingkat bunga, dan lain-lain.

\section{DAFTAR PUSTAKA}

Aji Supriyanto. (2005). Pengantar Teknologi Informasi. Jakarta: Salemba Infoktek

Agus Sartono, 2001. Manajemen Keuangan Teori dan Aplikasi .Yogyakarta :BPEFYOGYAKARTA

Auditing Standard Board. 1995. Statemen on Auditing Standards Number 78. American Institute of Certified Public Accountants, Inc

Caskery, J., dan M. Hanlon. 2005. Do Devidens Indicate Honesty? The relation Between dividends and the quality of earnings. Workpaper, University Of Michigan.

Deddi nurdiawan. 2007. Akuntansi Sektor Publikasi. Salemba Empat : Jakarta.

Deddi Nurdiawan, Iswahyudi Sondi Putra, Maulidah Rahmawati. 2007. Akuntansi Pemerintah. Salemba Empat: Jakarta

Devaraj, S. and Kohli, R. 2003. "Performance Impact Of Information Technology: Is Actual Usage The Missing Link? "Management Science. (49:3). Pp.

Easterbrook, F. 1984. Two agency-cost explanations of dividends. The American Ekonomic Review 74:650-659.

Ghozali, Imam. 2005. Aplikasi Analisis Multivariate Dengan Program SPSS”. Semarang: Badan Penerbitan Universitas Diponegoro

Glasement, J. 2005. When Numbers don't add up. Kiplinger's (august):32-34.

Goodhue, D.I dan Thompson.R.L.1995.'Task - Technology and Individual Performance”. Mis Quartely, Juni 2013-236.

Hanafi, Mamduh. (2004). "Manajemen Keuangan”, BPFE, Yogyakarta

IAI. 2009. Standar Akuntansi Keuangan. Jakarta: Salemba Empat

Jones, R dan M. Pendlebury. 2000. Public Sector Accounting. 5th Edition. Pitman Publishing, London

Kieso, Donald E. and Jerry J. Weygandt. 2005. Accounting Principles. Canada : John Wiley \& Sons,Inc

Lintner, J. 1956. Distribution of Incomes of Corporation Among Dividends, Retained Earnings, and Taxes. The American Economic Review, Vol 46, No. 2:97-113.

O’Brien, James A. 2004. Management Information System : Managing Information Tecnology in The Business Enterprise. Sixth Edition. Mc. Graw-Hill. New York, USA.

Rezaee, Zabihollah.2002. Prevention and detection. Canada.

Santoso, Urip dan Yohanes,J.P. 2008. PEngaruh penerapan akuntansi sector public terhadap akuntabilitas kinerja instansi pemerintah dalam mencegah fraud.Jurnal adminsitrasi Bisnis Vol. 4

Singarimbun, Masri dan Sofian Effendi. 1995. Metode Peneltiain Survei. Jakarta: PT Pustaka LP3ES Indonesia.

Suwardjono. 2005. Teori Akuntansi. Perekayasaan Pelaporan Keuangan.Edisi Ketiga, Yogyakarta : BPFE. 
Thompson, Ronald L, Haggings, Christoper A., dan Howell, Jane M. (1991), " Personal Computing : Toward A Conceptual Model Of Utilazion”, MisQuarterly, pp.125-143.

Tjhai Fung Jing. 2003. "Analisis Faktor-Faktor Yang Mempengaruhi Pemanfaatan Teknologi Informasi Terhadap Kinerja Akuntan Public”, Jurnal Bisnis Dan Akuntansi 5 (1):1-26.

Wibowo,., Wijaya, Winny. 2009. Pengaruh Penerapan Fraud Earlywarning System (FEWS) Terhadap Aktivitas Bisnis Perusahaan. Jurnal Infomasi, Perpajakan, Akuntansi dan Keuangan Public

Wilkonson, Joseph. W., Michel J. Cerullo, Vasant Raval, Bernard Wong-On-Wing. 2000. Accounting Information System. $4^{\text {th }}$ Edition. Canada : John Willey \& Sons, Inc

Wolk, Harry. I., Micheal G, Terney., James. L. Dodd, 2001. Accounting Theory : Conceptual and Sintitutional Approach, Fifth Edition, South Western Collage Publishing, Cincinnati, Ohio.

Zuhroh, D., Sukmawati. 2003. “ Analisis Pengaruh Luas Pengungkapan Sosial dalam Laporan Tahunan Perusahaan Terhadap Reaksi Investor (Studi Kasus Pada Perusahaan Perusahaan High Profile Di BEJ)". Symposium Nasional Akuntansi VI (SNA VI), 1314-1341. 